\title{
Intersections
}

Canadian Journal of Music

Revue canadienne de musique

\section{The Late Voice: Time, Age and Experience in Popular Music. By \\ Richard Elliott. London: Bloomsbury Academic Press, 2015. [ISBN9781628921182 (hardcover) \$120.00] Endnotes, bilbliography, index}

\section{Nicholas Godsoe}

Volume 36, numéro 2, 2016

URI : https://id.erudit.org/iderudit/1051606ar

DOI : https://doi.org/10.7202/1051606ar

Aller au sommaire du numéro

Éditeur(s)

Canadian University Music Society / Société de musique des universités canadiennes

ISSN

1911-0146 (imprimé)

1918-512X (numérique)

Découvrir la revue

Citer ce compte rendu

Godsoe, C. N. (2016). Compte rendu de [The Late Voice: Time, Age and

Experience in Popular Music. By Richard Elliott. London: Bloomsbury Academic Press, 2015. [ISBN9781628921182 (hardcover) \$120.00] Endnotes, bibliography,

index]. Intersections, 36(2), 131-133. https://doi.org/10.7202/1051606ar

Copyright @ Canadian University Music Society / Société de musique des universités canadiennes, 2018 lntersections

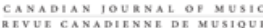

Ce document est protégé par la loi sur le droit d'auteur. L'utilisation des services d'Érudit (y compris la reproduction) est assujettie à sa politique d'utilisation que vous pouvez consulter en ligne.

https://apropos.erudit.org/fr/usagers/politique-dutilisation/ 
The Late Voice: Time, Age and Experience in Popular Music. By Richard Elliott. London: Bloomsbury Academic Press, 2015. [ISBN9781628921182 (hardcover) $\$ 120.00]$ Endnotes, bibliography, index.

Richard Elliott's 2015 book The Late Voice: Time, Age and Experience in Popular Music readily responds to an increasingly prominent awareness of age in the context of popular music studies. Like other scholars who bring together popular music and age, Elliott's work claims significance in that "Popular music artists, as performers in the public eye, offer a privileged site for the witnessing and analysis of aging and its mediation" (4). The performance of popular music invites audiences to see and hear the implications of age, and at the same time, popular music can act as an "acoustic mirror" that encourages listeners to contemplate the passing of time on their own bodies (220). Framed in such terms, the ability for a popular music artist to evoke impressions of age or lateness in their work is a powerful notion. Elliott addresses this with his own framework-his concept of the late voice. In contrast to previous scholarship, Elliott's notion of the late voice is more concerned with how representations of time, and age experience can be identified and understood in the work of popular musicians, regardless of how old they actually are. Understanding musical expressions of what Elliott calls "early lateness," then, will allow scholars to look beyond examining issues related to actual, physical aging in popular music; Elliott advocates for understanding lateness as an aesthetic construct rather than a life chapter. This book, then, examines the life, lyrics and music of Ralph Stanley, Leonard Cohen, Frank Sinatra, Bob Dylan, Neil Young and Joni Mitchell in an effort to better understand how representations of latenessrepresentations of time, age and experience-characterize these artists and their music at varied stages in their respective careers.

Two of The Late Voice's strongest features are apparent from the text's introduction. In less than ten pages, Elliott showcases his robust understanding of the subject matter in a comprehensive literature review. Here Elliott succinctly draws the reader's attention to the mandate of existing scholarship that considers the relationship between aging and popular music; most notably Andy Bennett's Music, Style, and Aging: Growing Old Disgracefully? (2013), Shelia Whiteley's Too Much Too Yong: Popular Music, Age, and Gender (2005) and Ros Jennings and Abigail Gardner's 'Rock On': Women, Aging, and Popular Music (2012). Simultaneously, Elliott seamlessly draws attention to what is missing in such texts, and in doing so carves a convincing space for his own research and ideas, and points out the fact that musical lateness is not necessarily tied to physical lateness: " ... while there seemed to be a fit between chronologically late work (work created by artists late in their lives and/or careers) and themes 
of time, age and experience, there was nothing to exclude such a connection with artists at a much earlier time in their lives" (3). Elliott then clears any doubt a reader may have with regards to this seemingly unusual hypothesis, and articulates what exactly he means by lateness, and how this is used as a point of analysis throughout the book:

Lateness ... refers to five primary issues: chronology (the stage in an artist's career); the vocal act (the ability to convincingly portray experience); afterlife (posthumous careers made possible by recorded sound); retrospection (how voices 'look back' or anticipate looking back); and the writing of age, experience, lateness and loss into song texts (4).

Throughout the entire text, Elliott is consistent in framing his own ideas in the context of what scholars have already said about particular musicians, works, and concepts, and is relentless with the application of his conceptual framework as established in the introduction. While the mantra of "time, age and experience" is repeated and used on the verge of excess, these two recurring features-thorough scholarly context and consistent conceptual application-gives Elliott's book the cohesiveness it requires to be effective. While this may seem like a trivial observation, the scope of Elliott's book could easily succumb to a scattered, disordered collection of observations given the depth and magnitude of the issues it addresses in the context of so many different popular musicians.

Elliott acknowledges that the nature of the project at hand may indeed be viewed as "ambitious and impertinent" (8), and a quick examination of the book's five chapters would appear to affirm that. But, as mentioned, the chapters are able to operate in a cohesive way owing to how carefully the chapters are prepared and executed. While chapters two through five are the case study chapters which discuss artists and their music at length, chapter one, titled "Time, Age, Experience and Voice" is almost a second introduction, and takes the time to further set the stage through detailed discussions on each of the concepts included in the chapter's title. This wholly interdisciplinary chapter brings together thought on how literature, poetry, film, fiction and music alike are able to engage with and evoke themes of time, age, experience and voice. The chapter concludes with a sub-section titled "Case Studies," again, taking the time to bring the large amount of information packed in the 53 pages previous into context.

The book's case studies, taken as a whole, illustrate two general but key points. First, the concept of early lateness in popular music is very much real, and much can be garnered through critically considering how this operates. When discussing Frank Sinatra, for example, Elliott demonstrates how the singer expresses more of a late voice in the middle part of his career; while Sinatra's voice certainly becomes huskier and more restrained as he ages, there are other ways to interpret lateness. Elliott believes this can be seen in Sinatra's middle period, in the 1950s and 1960s. After a detailed biographical, lyrical and musical analysis of Sinatra, Elliott elaborates:

Sinatra's greatest, most assertive presentation of lateness, when thought of as a combination of age, time and experience, is that found in his long middle 
period ... this long middle period is a more solid representation and produces a body of work that seems to call out for a consideration of time, age, and experience-and for a dialectic of mastery and submission-in a way that his early and late work does not (p. 124).

Similarly, Elliott describes how musicians like Bob Dylan situate themselves as older, wise men before they actually become physically old. Through an examination of Dylan's early song texts, Elliott reveals that themes of time, nostalgia and dislocation imply a sense of experienced, elder wisdom. For example, at age twenty, Dylan was singing about how he was "born very far from where I'm supposed to be ..." in the song "No Direction Home" (154). Elliott is quick to point out the obscurity in this: "Dylan's claim to being born a long way from home is an odd one because it could also be construed as saying he was born experienced" (155). This sense of displacement at such an early age implies Dylan is experienced-a manifestation of Elliott's notion of early lateness - and leaves audiences both then and now listening to a young Bob Dylan's music with the unintentional assumption that an old, wise man is singing to them (159).

The second key point illustrated in these case studies is the notion that lateness can be expressed in many different ways. Lateness can be observed in Ralph Stanley by examining his performance of his own music differently over time. While Neil Young's singing voice remains consistent over time, lateness can be observed in his increasingly reflective guitar playing. Lateness can be located in young Joni Mitchell's confessional song texts; the confessional nature of her early work implies experience.

The string of nuanced case studies presented in this text indeed establish that the late voice is a legitimate, new way to consider aging in popular music, but the text in many ways begs more questions than answers. None of the case studies feel final or totally complete; they simply raise an interesting point, explore it for a bit, and then Elliott moves on. But, I think this was Elliott's point. At the end of the first chapter, he sends the reader into the case studies describing them as "invitations to thinking"; he ensures that the reader is aware that while this is by no means a complete, comprehensive or conclusive study, he hopes that the approaches he takes in his analyses will inspire others to apply the concept of the late voice to other popular artists (58). I found this to be a refreshingly modest scholarly tone. It is encouraging that Elliott is more concerned with moving a conversation forward than insisting on proving an argument; a mature tact that certainly implies an experienced authorial voice.

C. Nicholas Godsoe

\section{BIOGRAPHY}

Nicholas Godsoe (BMus '15) has a full-time administrative role with MusiCounts, a Toronto-based organization running several programs that focus on supporting music education in Canada. Following his degree at Mount Allison, Nicholas went on to graduate studies in Musicology at the University of Toronto. 